\title{
VALLÁSI SZOCIALIZÁCIÓ ÉS HATÁSAI
}

\section{RELIGIOUS SOCIALISATION AND ITS EFFECTS}

\author{
Pusztai Gabriella \\ DSc, egyetemi tanár, Debreceni Egyetem \\ pusztai.gabriella@arts.unideb.hu
}

\begin{abstract}
ÖSSZEFOGLALÁS
Magyarországon minden negyedik fiatal részesül vallásos nevelésben, de a környezetében szinte mindenki találkozik a vallásosság valamely formájával. Tanulmányunk a vallási szocializációval, a vallásos családban, egyházi intézményben való nevelkedéssel, a vallásosság tanulásra, iskolai pályafutásra, iskolai végzettségre gyakorolt hatásával foglalkozik. Előbb a vallási szocializáció fogalmának értelmezési lehetőségeit, majd a vallásos nevelés iskolai előmenetelre gyakorolt hatását, végül a hazai egyházi iskolákkal foglalkozó kutatások legfontosabb megállapításait foglaljuk össze.
\end{abstract}

\section{ABSTRACT}

Although only about every fourth young person in Hungary receives religious upbringing in his family, this is a social factor that we cannot ignore, even if an individual was not raised in a religious spirit, in a friendship, neighbourhood and school environment. In our study, we draw attention to some research results that deal with religious socialization, the effect of religious upbringing and education in faith-based schools on school career. Our paper consists of three parts: (1) the interpretation of the concept of religious socialization (2) the effect of religiosity on school career, and finally, (3) we summarize the most important findings of research concerning faith-based schools in Hungary.

Kulcsszavak: vallásosság, vallási szocializáció, iskolázottság, egyházi iskola

Keywords: religiosity, religious socialisation, education, church-run schools

\section{A VALLÁSI SZOCIALIZÁCIÓ}

Kutatásaink során tapasztaltuk, hogy az egyén maga sem látja egyértelmü, objektív ténynek a vallási önbesorolását, a személyes és közösségi vallásgyakorlata korábbi, illetve aktuális intenzitását, a hite - illetve a spiritualitása - tartalmát (Pusztai, 2004, 120.). A 2012-es adatok szerint a magyar fiatalok egyharmada 
(Pusztai, 2015), 2016-ban ${ }^{1}$ kevesebb mint egynegyed állította magáról, hogy vallásosan nevelték. Közülük minden ötödik egyháziasnak mondja magát, bő kétharmaduk a maga módján vallásos, miközben a vallásos nevelésben nem részesülö fiatalok bő egyharmada vallásos. A Tomka-féle ötfokú skála (Tomka, 1973) a vallásosság különböző típusainak érzékeny mérésére törekedett, ám a vallásosság különböző dimenzióiban mért adatok divergenciát mutatnak. A családi és intézményi vallásos nevelés formájának, tartalmának, huzamosságának, ágenseinek és eredményességének, s magának a vallásosságnak az érzékelése erősen kultúraés környezetfüggő, s a kutatók társadalomfelfogása és terepérzékenysége további eltéréseket eredményezhet az adatok értelmezésében.

A vallási szocializációt, függetlenül az eredményétől, olyan folyamatként értelmezzük, melynek során nemcsak az egyén transzcendenshez való viszonya, hanem identitása, életvezetése, társadalmi szerepvállalása, kapcsolatai, sőt a természeti környezethez való viszonya is formálódik (Fowler-Dell, 2006). De hogyan, miként zajlik ez a folyamat? A vallási szocializáció korábban domináns rekonstrukciós felfogásától konstruktivista koncepciók különböztethetők meg abból a szempontból, hogy a kutatók mit tartanak a folyamat céljának, mozgatórugójának, az eredményes vallási transzmisszió indikátorának, kit tartanak a kulcsszereplőjének, s milyen hatóerőt tulajdonítanak az egyéni és intézményi szereppartnereknek.

A klasszikus vallási szocializációs elméletek logikája szerint a folyamat lényege az előző generációk nézeteinek, norma- és szokásrendjének rekonstrukciója az új generációkban. Ebben az értelemben a vallási szocializáció lineáris, teleologikus, lezárható folyamat, mely a gyermek-, serdülö- és ifjúkor fejlödési szakaszaiban történik (Fowler-Dell, 2006). A fejlődésalapú koncepciók lényegében egységes eredményt tételeznek fel, például az ún. vallási érettséget (Benson et al., 1993). Az eredményesség kritériuma az, hogy az egyén internalizálja mindazt, ami a vallási rendszer kontextusában érvényes (Sherkat, 2003).

A vallási szocializáció rekonstrukciós felfogása szerint egyértelmúen azonosíthatók a hatást gyakorló szocializációs ágensek, akiknek szándéka a kompakt kultúraátadás, míg az új generáció az elvárásoknak megfelelve, passzív befogadóként lép a meglevő struktúrák keretei közé. A funkcionalitást kiemelő elméletek szerint ez a társadalmi integráció útja, a kritikai irányzatok szerint viszont a szocializációs ágensek hatalommal és kényszerítő eszközökkel lépnek fel a kontinuitás érdekében, ami tagadáshoz, lázadáshoz vezethet (Todd et al., 2003).

Noha a vallási szocializáció pszichológiai elméletei az egyén vallásossággal kapcsolatos fejlődési pályaívére koncentrálnak, mint James W. Fowler kognitív fejlödési elmélete, a környezet hatását nem lehet tagadni. A kutatások egyik vonulata a szülő közvetlen hatását tekinti döntőnek, s a hit szülők általi tovább-

\footnotetext{
${ }^{1}$ Az adatok forrása a Magyar Ifjúság Kutatás 2016.
} 
adásának törvényszerüségeit, a transzmisszió sikerét befolyásoló szülöi iskolázottságot, anyagi státust, családtípust, a vallásos szülő és a fiatal nemét, a szülői nevelési stílust, illetve a családi kapcsolatok tőkeerejét, a szülő gyermekre szánt idejét, figyelmét, támogatását vizsgálja (Todd et al., 2003). A channeling teória szerint viszont a szülők hatása közvetett, mivel egy meghatározott kapcsolathálóba, szervezetbe csatornázzák be gyermekeiket, s a vallásoktatás szocializációs hatása is úgy érvényesül, hogy a szülő által választott közösségekben a vallásosság iránt érdeklődő kortársak érhetők el (Pusztai, 2009).

A vallási szocializáció rekonstrukciós értelmezését már a spiritualitás fejlödéselméleti megközelítése is árnyalni kezdte, mely annak életkori fázisait vizsgálva megkülönböztette a konvencionális vallásosságot az individuatív-reflektív vallásosságtól, amely az önálló jelentésalkotás felé halad (Fowler-Dell, 2006), sőt, feltételezték, hogy vannak olyan fejlődési fázisok is - az univerzalizáló és transzperszonális szakaszok - melyekbe nem is mindenki jut el.

Az ezredforduló után a vallási szocializáció interpretatív felfogása felé fordultak kutatásaink. Ezek szerint a vallási szocializáció főszereplöje a releváns interakciókat feldolgozó egyén, aki maga munkálkodik ön- és világértelmezése formálódásának mühelyében (Sherkat, 2003, 151.). Az episztemológiai paradigmaváltás nyomán világossá vált, hogy a vallásossággal kapcsolatos értékek, attitüdök, magatartásminták és tevékenységek jelentése azért változatos, mert az egyén önmagában vagy társaival kölcsönhatásban megalkotja, konstruálja azokat. A konstruktivista paradigma szerint az egyén a vallásgyakorlatban és a hit tartalmi kérdéseiben felfedezőként és kísérletezőként szerepel. A vallási kínálat sokfélesége okozta bizonytalanság is állandó újrakonstruálásra kényszeríti, így alkalmi, reflexszerü - vagyis nem a tudatosságot tükrözö - viszonyulásmódokat is létrehoz. Mások szerint viszont az egyén kritikusan, és saját vallásosságával kapcsolatos választásait is folytonos önkritikával szemlélve - vagy autonóm módon, aktuális kapcsolatai hatására többé-kevéssé tudatosan - finomítja vallásosságát (Martí, 2015). Eredménye reflektív vagy reflexív vallásosság is lehet (Hunt, 2015).

A nagyfokú vallási-világnézeti heterogenitás közepette a többség számára bonyolult feladat hitének tartalmi meghatározása (Martí, 2015). Ha individuális konstrukcióként értelmezzük a vallásosságot, a vallási szocializáció folyamata és eredménye egyénenként eltérő, igaz, így a szocializáció kifejezés is szinte értelmét veszti. Kutatásaink azt igazolják, hogy az egyén vallási meggyőződése mikrokörnyezetében, értelmezö közösségeiben formálódik, velük közösen értelmezi és alkotja újra és újra. A vallásos nevelés tehát nem más, mint az összekapcsolódó egyének közös jelentésalkotó tevékenysége, s ennek szüntelen ismétlődése az életút során.

Az interpretatív felfogás empirikus megragadása azonban kihívást jelent a kutatóknak. A vallásosság fogalmának mérhetővé tétele, sztenderdizálása önmagában sem könnyü feladat. Kényelmesebb a konvencionális mutatók pozitivista, 
kvantitatív használata, ami a vallási szocializáció rekonstrukciós modelljét élteti tovább, ami elsősorban a performatív, külső vallásosságot, ennek rituális dimenzióját tudja megragadni, vagy a hit normatív értelmezése felé hajlik (Benson et al., 1993). A kvantitatív empirikus kutatások valójában nem tudnak mit kezdeni azzal a ténnyel, hogy a hittel kapcsolatos egyéni állásfoglalások nem feltétlenül eredményeznek egyforma nézeteket, vallásgyakorlatot. Ezért van az, hogy az empirikus vizsgálatok sokszor a vallási szocializáció sikertelenségét állapítják meg. 2017 nyarán családok három nemzedékében gyüjtött harminchat kvalitatív interjú feldolgozása nyomán arra a következtetésre jutottunk, hogy az egyén vallási szocializációja során a mintakövetéssel szemben döntő jelentősége van az individuális és közösségi szinten folyó folyamatos jelentésalkotásnak. Így a vallásosság performatív elemei helyett inkább konzekvenciális dimenziója válik érvényes adattá a kutató számára, s az a kérdés kerül előtérbe, hogy a vallásosság különböző formái milyen hatással vannak az egyén döntéseire, életútjára.

\section{A VALLÁSOSSÁG ÉS ISKOLÁZOTTSÁG}

Az oktatáskutatók jelentős része a tanulók, intézmények, oktatási rendszerek eredményességét elősegítő tényezőket keresi. Tény, hogy a magas státusú tanulóknak sokkal nagyobb esélyük van tanulmányi sikereket elérni a többieknél, azonban kérdés, hogy milyen erőforrások révén lehetnek eredményesek az alacsonyabb iskolázottságú szülők gyermekei. Körükben végzett vizsgálatainkban rendre tetten értük egy igen hatékony erőforrás, a vallási közösségekben elérhető társadalmi tőke befolyását (Pusztai, 2004, 2009). Így felmerült a kérdés, milyen kapcsolat van a vallásos nevelés és a tanulmányi eredményesség között.

Sokan fordítva teszik fel a kérdést: hogyan hat az iskolázottság a vallásosságra, s arra a következtetésre jutnak, hogy az iskolázottság növekedése erodálja a társadalom vallásosságát (Nagy, 2005). Magyarázatként az oktatás illuminációs hatását, az oktatási intézmények szekuláris közegének, a nyitott társadalom kulturális relativizmusának, illetve az ateista diktatúrákban müködő oktatási rendszerek nyomásának vagy örökségének befolyását említik (Sherkat, 2003). A racionális döntéselmélet egyrészt azzal magyarázza a jelenséget, hogy a vallási közösségek tagjai státusuk erősítéséhez hatékonyan alkalmazzák a vallási kapcsolathálóban elérhető szívességbankot és információs csatornákat, másrészt, hogy a vallási szervezetek, közösségek is a magas státusúakra vadásznak (McFarland et al., 2011).

Bennünket azonban a vallásosság mint az iskolai eredményességhez vezető lehetséges alternatív út izgat. Max Weber óta visszatérő hipotézis, hogy a vallási normarendszer társadalmi mobilitást serkentő tényező. Kutatások tárgya, hogy a vallások, felekezetek normarendszerének eltérései milyen eredményességkü- 
lönbségeket vonnak maguk után (Lehrer, 2006). A felekezeti hovatartozás és a vallásosság iskolázottságra gyakorolt hatása azonban régiónként és vallási közösségenként eltérő, s időben is változó előjelü és mértékű (Lehrer, 2006; McFarland et al., 2011). Magyarországon az alapvető társadalmi státusmutatók az 1970-es években még negatív irányban függtek össze a vallásossággal (Hegedüs, 2000), azonban az ezredforduló után a vallásos fiatalok körében nőtt a magasabb státusúak aránya (Hámori-Rosta, 2013; Pusztai, 2015).

A vallásosság bizonyos mutatói iskolai eredményelőnyhöz vezetnek: többváltozós elemzéskor az azonos szülői iskolázottsági háttérrel rendelkezők közül eredményesebbeknek bizonyultak azok a középiskolások, akiknek vallásos tanulókból állt a baráti körük, sőt, a döntően vallásos baráti körhöz kötődő fiatalok iskolai közösségbeli túlsúlya iskolai szinten is pozitív hatással bírt az eredményességre (Pusztai, 2004). A vallásos kapcsolatháló olyan sajátos társadalmi tőkét hozott létre az iskolaközösségekben, amelyből azok a tanulók is profitálhattak, akik maguk nem voltak vallásosak. Különböző iskolaszektorok összehasonlításakor azt tapasztaltuk, hogy a kisközösségi vallásgyakorlat jelentősebb hozzájárulást ad az eredményességhez, mint az individuális (Pusztai, 2009). A vallásgyakorló fiatal felnőttek közül többen terveztek továbbtanulást, többen kerültek be a felsőoktatásba, s kétszer annyian szereztek diplomát, mint a nem vallásosak vagy a magányos vallásgyakorlók (Pusztai, 2015).

A vallásgyakorlatnak kétféle irányból lehet hatása a tanulmányi előmenetelre: az egyik a közvetlen, attitüdöket, értékpreferenciákat átformáló hatás, a másik az indirekt hatás, amely a kapcsolatháló közvetítésével jut el az egyénhez (Iannaccone, 1998; Lehrer, 2006). A vallásos neveltetés során felhalmozott tapasztalatok a képességfejlődésre, a teljesítményre orientáló normák sikeres interiorizálására gyakorolt hatása érvényesül. A közösségi rítusokban való jártasság megkönnyíti az oktatási intézményrendszerben müködő időbeosztáshoz, intézményi szerepstruktúrához való alkalmazkodást (Lehrer, 2006). A kisközösségi vallásgyakorlatban fejlődik az önkifejezés és a kreativitás; a vallásos nevelés kognitív dimenziója, a szentírás-magyarázat az olvasás-szövegértés képességének fejlődésére, a múveltség gyarapodására van hatással; a személyes vallásgyakorlat pedig a kritikus önértékelést pallérozza (Iannaccone, 1998; Pusztai, 2009, 70.).

A vertikális társadalmi réteghatárokon átívelő vallási kapcsolathálóban bizalom, információk és normabiztonság termelődik, amelynek haszna a deviáns viselkedés, a rizikómagatartás mérséklése és a magas teljesítmény, a szolidaritás (Pusztai, 2009). A kapcsolathálózati megközelítés a networkök méretét és öszszetételét tartja döntőnek. Korábban egyes kicsi, zárt vallási csoportok elzárták gyermekeiket a felsőoktatástól, így körükben az iskolázatlanok domináltak, azonban a szintén zárt networkü, modern, kisközösségi vallásosság kritikus, alkotó, élményalapú vallásgyakorlatot honosított meg, éppen a társadalom fiatalabb, képzettebb rétegei körében (Andorka, 1994; Bacskai, 2017). 


\section{VALLÁSOS NEVELÉS A CSALÁDBAN ÉS A FELEKEZETI ISKOLÁBAN}

A vallásos identitású szülőtársadalom nevelési elveivel és praxisával több kutatásunk foglalkozik. A nevelési értékek meghatározó tengelye az egyéni-közösségi tengely, amelyen a vallásosak közelebb állnak a közösségi értékek pólusához, míg a nem vallásosaknál az egyéni szabadság értéke felülírja a közösséggel szolidáris eszményt. Az autonómia-külső kontroll tengelyen mutatkozó eltérések rámutatnak, hogy a vallásos nevelés rendszerében a gyermeket később emancipálják, míg a nem vallásos szülők inkább hajlanak a gyermek korai erkölcsi autonómiájának feltételezésére (Pusztai, 2014). A legmagasabban kvalifikált vallásosak körében a közösségi értékek prioritásának megmaradása mellett az individuális autonómia súlya növekszik. A vallásgyakorló szülők nagyobb hangsúlyt helyeznek a családi normákkal ellentétes tevékenységek limitálására a korábbi életszakaszban, a későbbi években azonban csökkentik a kontrollt. A fiatalabb életkorban a felekezeti iskolások szülei elsősorban nem a tanulmányi munka ellenőrzésére koncentrálnak gyermekükkel való kommunikációjukban, hanem a családban elfogadottól eltérő normákat közvetítő hatások minimalizálására (Pusztai, 2009).

Egy 2016-os elemzésünk szerint a szülők vallásossága szignifikánsan erősíti a család stabilitásának valószínüségét. A közösségi vallásgyakorlattal bírók kiemelkedően stabil családszerkezetben élnek, és a család stabilitását veszélyeztető konfliktusok fele olyan arányban fordulnak elő náluk. Megállapítottuk, hogy a vallásosság az iskolai végzettségnél, a házasfelek képzettségi homogámiájánál és a foglalkoztatottságnál határozottabban támogatja a család stabilitását. A privatizálódott vallásosságú szülőpárok családi stabilitása gyengébb (Pusztai, 2016).

A vallásos szellemü nevelés egyik lehetséges színtere az egyházi iskola. A hazai oktatási rendszer elmúlt harminc évben bekövetkezett átstrukturálódásának egyik legizgalmasabb kihívása volt, hogy a deklaráltan ateista iskolai nevelés évtizedei után a különböző társadalmi-kulturális csoportok hogyan képesek elérni, hogy gyermekeik a családi szocializációval összeegyeztethető oktatáshoz és neveléshez jussanak. Majd három évtized alatt az egyházi iskolaválasztók száma a tanulókorú népesség számának csökkenése mellett is egyértelmüen növekedett. Az ezredfordulóig a szektor mérete $10 \%$ alatt maradt. 2005 körül kezdődött a lassú, majd a 2010/2011. tanévtől dinamikusabb növekedés, s a szektor mérete mára alapfokon elérte a 15 , középfokon meghaladta a $20 \%$-ot. A fenntartók felekezeti arányai a népességen belüli arányokat tükrözik, majd minden második iskola katolikus, egynegyedük református, minden huszadik evangélikus, de tizedüket zsidó közösségek, neoprotestáns egyházak, Krisna-tudatúak, buddhisták és muszlimok mủködtetik.

Az egyházak oktatáspolitikai stratégiaépítésében kimutatható változások egyik fő trendje a hátrányosabb helyzetű régiók, tanulói rétegek felé fordulás és a tár- 
sadalmi egyenlötlenségek enyhítése. Leginkább a hátrányos helyzetủ régiókban és olyan kisebb településeken növelték jelenlétüket az egyházi iskolák, ahol más fenntartó intézményei nem tudtak megbirkózni az iskolafenntartói és a pedagógiai kihívásokkal (Pusztai, 2014; Morvai, 2018). A peremhelyzetủ lakókörnyezetekben múködő egyházi iskolák kultúraazonos pedagógiájának kulcseleme, hogy az egyén transzcendens eredetü és közösségi értékére és felelősségére építenek (Bacskai, 2017).

A felekezeti oktatási intézmények iránti társadalmi igényekről először az ezredfordulón készült átfogó vizsgálat (Pusztai, 2004). 2016-ban a 15-29 éves fiatalok majd tizede válaszolta, hogy egyházi oktatási intézménybe járt. Az ezredfordulón a felekezeti iskolát választók összességében jóval vallásosabbak voltak, mint a korosztályuk, de a diákok harmada nem vallásgyakorló családokból érkezett (Pusztai, 2004). A templomba járó szülőknek ma is nagyjából háromszor akkora esélye van egyházi iskolát választani, mint államit, s ha a vallásosságot is bevonjuk az elemzésbe, a szülők iskolázottsága nincs szignifikáns hatással az iskolai szektor választására (Pusztai, 2016). Az egyházi intézményben tapasztalatot szerzők kétharmadát nevelték vallásos szellemben, hatvan százalékuk egyházközségi hittanra is járt. Az egyházi intézmények diákjainak több mint háromnegyede vallásosként azonosítja magát, s egyharmaduk az egyház tanítását követőnek vallja magát. Az egyházi iskolások bö háromnegyede a 2016-os válaszadás pillanatában is valamely vallási felekezet, közösség tagjának érezte magát, miközben csak egyharmaduk volt rendszeres templomba járó és imádkozó. Körükben is egyértelműen kitapintható a vallásgyakorlat egyénre szabott konstrukciója.

Az egyházi oktatási intézményekbe járók között felülreprezentáltan vannak jelen a kisvárosokban élők és a diplomás szülők gyermekei. A fővárosi és vidéki egyházi iskolások közötti markáns eltérés ma is tapasztalható, a fővárosi egyházi intézményekben a diplomás szülők aránya kétszer annyi, mint a többi szülö körében, ám vidéken nincs ekkora eltérés a szektorok között. Tévedés lenne arra következtetni, hogy az egyházak társadalmi státus szerint szelektálnak. Valójában a vallásos és nem vallásos csoportok társadalmi összetételében zajló komoly átrendeződés érezteti a hatását. A 2016-os adatok szerint a magukat az egyház tanítása szerint vallásosnak mondó fiatalok között jelentősen felül vannak reprezentálva a diplomás szülők gyermekei. Ök általában a vallásosak között tíz százalékkal többen vannak, mint a nem vallásosak körében, de a fövárosban a vallásosak végzettségi előnye háromszoros. A vallási öndefiníciós paletta két szélső pólusához tartozók aránya lecsökkent, s az utóbbi évtizedekben mind az egyház tanítása szerint vallásosak, mind a nem vallásosak társadalmi összetétele átrendeződött. Miközben az egyháziasan vallásosak iskolai végzettségi összetétele látványosan emelkedett, a más meggyőződésủeké alacsonyabb státus felé mozdult. 
1. táblázat. A vallási önbesorolás és a szülői iskolázottság

\begin{tabular}{|c|c|c|c|c|c|c|c|}
\hline \multicolumn{2}{|c|}{ A fiatal önbesorolása: } & 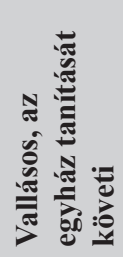 & 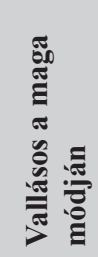 & 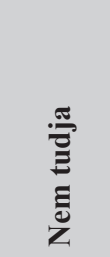 & 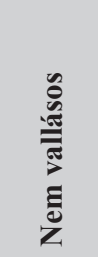 & 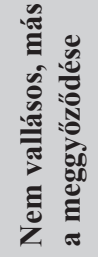 & $\begin{array}{l}\tilde{\tilde{N}} \\
\text { : } \\
\text { :0 }\end{array}$ \\
\hline \multicolumn{8}{|c|}{ A szülő iskolázottsága: } \\
\hline \multirow{4}{*}{ anya $(\mathrm{p}=0,000)$} & alapfok & $42,1 \%$ & $47,2 \%$ & $50,7 \%$ & $50,1 \%$ & $40,3 \%$ & $48,0 \%$ \\
\hline & középfok & $33,4 \%$ & $36,5 \%$ & $33,8 \%$ & $35,8 \%$ & $46,1 \%$ & $36,3 \%$ \\
\hline & felsőfok & $24,5 \%$ & $16,3 \%$ & $15,5 \%$ & $14,1 \%$ & $13,6 \%$ & $15,7 \%$ \\
\hline & $\mathrm{N}=$ & 413 & 3242 & 420 & 3240 & 345 & 7660 \\
\hline \multirow{4}{*}{ apa $(p=0,000)$} & alapfok & $49,8 \%$ & $57,8 \%$ & $58,5 \%$ & $57,7 \%$ & $55,3 \%$ & $57,3 \%$ \\
\hline & középfok & $27,3 \%$ & $26,6 \%$ & $29,00 \%$ & $28,6 \%$ & $31,5 \%$ & $27,9 \%$ \\
\hline & felsőfok & $22,9 \%$ & $15,6 \%$ & $12,6 \%$ & $13,6 \%$ & $13,2 \%$ & $14,9 \%$ \\
\hline & $\mathrm{N}=$ & 406 & 3195 & 414 & 3176 & 340 & 7531 \\
\hline
\end{tabular}

Magyar Ifjúság Kutatás 2016, Adjusted reisiduals >2,00, p =0,000

Szektorközi összehasonlítások szerint a felekezeti iskolákban jóval gazdagabb az extrakurrikuláris tevékenységek kínálata, mint más szektorokban (Pusztai, 2009). Ezekben a spirituális és közösségépítő tartalmak készségfejlesztéssel kombinálva jelennek meg (zene, sport). Az eredményesebb egyházi iskolák az inter- és intragenerációs kapcsolatteremtés és a bizalom kiépítésén keresztül igyekeznek megnyerni a tanuló együttmüködését (Dronkers-Róbert, 2005). Kutatásaink során rámutattunk, hogy a felekezeti iskolákhoz kötődők kiemelkedő szerepet tulajdonítanak a pedagógusoknak. Nagyobb arányban vélekednek úgy, hogy a nevelés szakértelmet kíván, $\mathrm{s}$ a tanulmányi kudarcokért nem csak a pedagógusok felelősek (Pusztai, 2014). Friss elemzések szerint az újabb, hátrányos helyzetủek által dominált egyházi iskolák eredményessége a tanulói összetétellel és az iskola települési környezetével kontrollálva egyes területeken eléri a régebbi egyházi iskolák szintjét a tanulást támogató légkör és az extrakurrikuláris aktivitás terén, s az új egyházi iskolák egy része jobban teljesít, mint a hasonló társadalmi kompozíciójú állami intézmények (Morvai, 2018). 


\section{ÖSSZEGZÉS}

A vallásos nevelést nem azonosítjuk a tervszerü, intézményesült valláspedagógiával, hanem szélesebb értelemben, szocializációs folyamatként értelmezzük. A vallási szocializáció fogalmát vizsgálva is megkülönböztetjük annak rekonstrukciós értelmezését egy modernebb, konstruktivista interpretációtól. A vallási nézetek sokszínűségével jellemezhető társadalmi környezetben a vallásosság nem mérhető a régi, sztenderdizált eszközökkel, mert konstrukciója individuális szintü, szituációhoz kötött, s jobbára reflexivitás jellemzi.

A vallásosságnak teljesítményre ösztönző és védőfaktor hatása van. Ez leginkább akkor hasznosul, amikor az egyént körülvevő értelmező közösség megerösíti az egyén vallási identitását. A vallásosságra épülő családi és iskolai nevelés koncepciójában ennek a kapcsolathálózatot erősitő, bizalomra építő pedagógiának az arculata tapintható ki, s csak másodlagos cél a tanulmányi eredményesség növelése.

A cikk a Nemzeti Kutatási, Fejlesztési és Innovációs Hivatal NKFI Alapjából támogatott K 119679 nyilvántartási számú, „Vallási változás Magyarországon” címü kutatási projekt támogatásával valósult meg.

\section{IRODALOM}

Andorka R. (1994): A Magyarországi Evangélikus Egyház és az evangélikusok helyzete és problémái 1941-töl. Valóság, 37, 5, 32-46.

Bacskai K. (szerk.) (2017): A felekezeti oktatás új negyedszázada. Debrecen: Debreceni Egyetemi Kiadó, https://dea.lib.unideb.hu/dea/bitstream/handle/2437/242377/Felekezeti_oktatas_beliv_ ebook.pdf?sequence=1\&isAllowed $=\mathrm{y}$

Benson, P. L. - Donahue, M. J. - Erickson, J. A. (1993): The Faith Maturity Scale. Research in the Social Scientific Study of Religion, 5, 1-26.

Dronkers, J. - Róbert P. (2005): A különbözö fenntartású iskolák hatékonysága. Educatio, 14, 3, 519-533. http://epa.oszk.hu/01500/01551/00033/pdf/874.pdf

Fowler, J. W. - Dell, M. L. (2006): Stages of Faith from Infancy through Adolescence. In: Roehlkepartain, E. C. - King, P. E. - Wagener, L. et al. (eds.): The Handbook of Spiritual Development in Childhood and Adolescence. Thousand Oaks: Sage, 34-45. DOI: 10.4135/9781412976657. n3, https://www.researchgate.net/publication/292654854_Stages_of_faith_from_infancy_ through_adolescence_Reflections_on_three_decades_of_faith_development_theory

Hámori Á. - Rosta G. (2013): Vallás és ifjúság. In: Bauer B. - Szabó A. (szerk.): Arctalan (?) nemzedék. Budapest: NCSSZI, 249-263. https://barankovics.hu/ff/honlapra/arctalan-nemzedek-1.pdf

Hegedüs R. (2000): A vallásosság alakulása Magyarországon a kilencvenes évek kutatásainak tükrében. Budapest: Corvinus Egyetem, http://phd.lib.uni-corvinus.hu/81/1/hegedus_rita.pdf

Hunt, S. J. (2015): Believing Vaguely: Religious Socialization and Christian Beliefs in Britain. Italian Journal of Sociology of Education, 7,3, 10-46. http://ijse.padovauniversitypress.it/system/ files/papers/2015_3_2.pdf 
Iannaccone, L. R. (1998): Introduction to the Economics of Religion. Journal of Economic Literature, 36, 3, 1465-1496. https://edisciplinas.usp.br/pluginfile.php/262957/mod_resource/content $/ 2 /$ Iannaccone $\% 20-\% 20$ Economics $\% 20$ of $\% 20$ Religion.pdf

Lehrer, E. (2006): Religion and High-school Graduation: A Comparative Analysis of Patterns for White and Black Young Women. Review of Economics of the Household, 4, 3, 277-293.

Martí, G. (2015): Religious Reflexivity: The Effect of Continual Novelty and Diversity on Individual Religiosity. Sociology of Religion, 76,1, 1-13. DOI: 10.1093/socrel/sru084, https://www.researchgate.net/publication/276247295_Religious_Reflexivity_The_Effect_of_Continual_Novelty_and_Diversity_on_Individual_Religiosity

McFarland, M. J. - Wright, B. R. E. - Weakliem, D. L. (2011): Educational Attainment and Religiosity: Exploring Variations by Religious Tradition. Sociology of Religion, 72, 2, 166-188. DOI: $10.1093 /$ socrel/srq065

Morvai L. (2018): Ora et labora? Egyházi középiskolások eredményessége a 2010 utáni szektorbővülést követően. (PhD-értekezés) Debrecen: Debreceni Egyetem, https://dea.lib.unideb.hu/ dea/bitstream/handle/2437/246928/MorvaiLaura_tezisek_titkositott.pdf?sequence=2\&isAllowed $=\mathrm{y}$

Nagy P. T. (2005): Iskolázottság és vallásosság Budapesten. Educatio, 14, 1, 75-94. http://www. edu-online.eu/hu/letoltes.php?fid=tartalomsor $/ 853$

Pusztai G. (2004): Iskola és közösség. Budapest: Gondolat Kiadó

Pusztai G. (2009): A társadalmi tőke és az iskola. Budapest: Új Mandátum Kiadó

Pusztai G. (2014): Felekezeti oktatás új szerepekben. Educatio, 23, 1, 50-66. http://folyoiratok.ofi. hu/sites/default/files/article_attachments/2014-1-tan5.pdf

Pusztai G. (2015): Pathways to Success in Higher Education. Frankfurt am Main: Peter Lang

Pusztai G. (2016): A szülők vallásossága mint a hatékony gyermeknevelés tőkeforrása. In: Földvári M. - Hakkel T. (szerk.): Riport a családokról. Budapest: L'Harmattan Kiadó, 427-447. https://www.academia.edu/35821271/A_sz $\%$ C3\%BClk_vall\%C3\%A1soss $\%$ C3\%A1ga_mint_a_ hat $\%$ C3\%A9kony gyermeknevel $\% \mathrm{C} 3 \% \mathrm{~A} 9 \mathrm{~s}$ _tkeforr\%C $3 \% \mathrm{~A} 1$ sa

Sherkat, D. (2003): Religious Socialization: Sources of Influence and Influences of Agency. In: Dillon, M. (ed.): Handbook of the Sociology of Religion. Cambridge: Cambridge University Press, 151-163. DOI: 10.1017/CBO9780511807961.012

Todd, F. M. - White, J. M. - Perlman, D. (2003): Religious Socialization. Journal of Adolescent Research, 18, 2, 169-187. http://citeseerx.ist.psu.edu/viewdoc/download?doi=10.1.1.1005.1491\&rep=rep1\&type $=$ pdf

Tomka M. (1973): A vallásosság mérése. Magyar Pszichológiai Szemle, 1-2, 122-135. http://acta. bibl.u-szeged.hu/25165/1/religiosa_001_018-031.pdf 